\title{
Contribution of the Women's Forestry Project to Rural Development in Shendi Area (Sudan)
}

\author{
Mahir S. Khaleel, Elshifa A. Merghani and Shadia E. Abbas \\ Sudan University of Science and Technology
}

\begin{abstract}
The northern parts of Sudan experienced the desertification problem since the 1980s. The SOS Sahel initiated a women's forestry programme (WFP) to support integrated rural development endeavors. The main objective of the study was to scrutinize the experience of the WFP through answering the following question: to what extent the project enhanced rural development endeavor in the area? The study was carried out in Shendi area in the River Nile state (Sudan). In addition to reviewing relevant secondary data, primary data was collected from village women using structured interviewing technique. As well, semi-structured interviews were carried out with village extension agents (VEAs), village leaders, and school teachers. Furthermore, focus group discussions were conducted with women in every village, with men in 4 villages, with WFP and FNC staff in Shendi and Elmatamma offices. The study demonstrated that women in rural areas have the potential to work in forestry and other rural development activities since their traditions were respected. The project opted for the Training of Trainers approach (TOT) as a mean to effective women participation. The character of the change brought about was mainly of psychological nature. However, social and to a lesser extent economic impacts were accredited.
\end{abstract}

Key words: Desertification, Environmental awareness, Village Extension Agents, Vegetable Home Gardens, Training

\section{Introduction}

The history of human existence and civilizations is intertwined with forests and trees. Forests are crucial for the goods and services they provide, which people all over the world depend on. The Food and Agriculture Organization of the United Nations (FAO) broadly sees a strong link between forests and two of the eight Millennium Development Goals: (1) eradicating extreme poverty and hunger, and (2) ensuring environmental sustainability. Primarily, forests provide food security for many of the world's rural poor while protecting biodiversity, contributing to carbon sequestration and maintaining and providing clean and reliable water sources for both urban and rural populations (Sam and Shepherd, 2011). Strategies to enhance the contributions of the world's forests to social development, livelihoods and poverty eradication are vital at a time when unsustainable practices and economic crises continue to threaten healthy forests and the people who depend upon them.

Korten (1990) sees development as "a process by which the members of a society increase their personal and institutional capacities to mobilize and manage resources to produce sustainable and justly distributed improvement in their quality of life, consistent with their own aspiration". In order to determine whether a society is developing, one must go beyond criteria based on indices of per capita income, the basic criterion is whether or not the society is a 'being for itself', i.e. its political, economic and cultural decisionmaking power is located within, (Paulo Freire in Burkey, 1993).

According to Dresner (2002) sustainable development is multi-faceted and includes four central components namely; economic, political, social, and environmental aspects. Political sustainability hinges upon the support of the majority of the community and must be effective over the long-term. Social sustainability requires that a project be integrated into, and connected with, a community's particular social structure. Environmental sustainability relates to the impact of a project on the local environment, with enhancement rather than degradation being the important outcome. Hence, implementing sustainable development means better environmental management. Environmental management is the "tool kit" used by a group of people to maintain their productivity without paying unacceptable environmental costs. This calls for an approach that allows development objectives to be achieved and at the same time places environmental concerns at the centre of the established development agenda (FAO, 1996).

The term "gender" refers to the socially constructed differences between men and women, as distinct from "sex", which refers to their biological differences (FAO, 2005). The term focused not only on women as an isolated and homogenous group, but on the roles and needs of both men and women. Given that women are usually in disadvantaged position as compared to men, promotion of gender equality implies an explicit attention to women's needs, interests and perspectives (Elobeid, 2009). 
Since the consideration of women's participation in development activities became more serious at the end of the 1970s, two major streams of theory and practice have been developed. The dominant approach, 'women in development' (WID), assumes that women have been left out of development and need to be integrated by others in order to benefit from it. The mechanism for this is generally special, women- only projects which focus on what are considered 'traditional' women's roles related to domestic activities. The alternative approach, 'gender and development' (GAD), is more critical of development. GAD theory asserts that women have always participated in development but from an unequal position and without acknowledgment. GAD supporters argue that the crucial constraints for women's advancement are the social structure and processes which create and maintain male superiority and female subordination (Humble, 1998).

Women are major actors in forestry throughout the developing world. They are affected differently than men by environmental degradation, deforestation and pollution. Hence, women have recognized themselves that they not only have the right to participate in environmental dilemmas but they have different relationship with environment including different needs, responsibilities and knowledge about natural resources (Asian Development Bank, 2013). The forestry development community is becoming increasingly aware of the important roles played by women in forestry and natural resource management. Many community forestry, agro forestry and farm forestry activities have recognized women`s major roles and have sought to promote their participation (Williams, 1992). According to Bristow (1998) in several parts of the world there is a long history of women's involvement in tree planting activities.

Human development is a process by which an individual develops self-respect, and becomes more selfconfident, self-reliant, cooperative and tolerant of others through becoming aware of his/her shortcomings as well as his/her potential for positive change. Hence, Human resource development is seen as the process of equipping individuals with the understanding, skills and access to information, knowledge and training that enables them to perform effectively (Elbasher, 2012). The term training refers to the acquisition of knowledge, skills, and competencies as a result of the teaching of vocational or practical skills and knowledge that relate to specific useful competencies. It is a planned activity designed to bring about changes in the individual and the community in terms of information, experiences, skills, rates of performances, methods of work, behavior and trends which make this individual or that group fit to do their jobs efficiently with high productivity (Suwaidan in Elbasher, 2012).

Sudan in general and the northern parts in particular have experienced the desertification problem since the 1980s. Consequently, people in the northern states have been affected in many ways. To name but a few: the drop in agricultural crops' productivity, diminish of arable land, and moving sand dunes that threatened residential areas. Such circumstances together with increased human population led to aggravation of the already existing poverty and other related problems (Bristow, 1998). Experiences elsewhere have proved that relief interventions were no solution under such conditions. Thus, it was believed that integrated rural development endeavors might be more effective. According to Shepherd (1998) the future of rural development is dependent upon empowering communities by raising their awareness of the potential for their involvement in the development process. Hence, many national and International organizations took the initiative to help the people through development projects (Elhadi, 2006). The SOS Sahel International Organization was among the international organizations that expressed willingness to support such integrated rural development endeavors. SOS has supported the agricultural and forestry sector in Sudan since 1985. It operated its first project in the River Nile State titled: The Village Extension Scheme (VES). The overall concern was to enhance environmental improvement through rural communities' mobilization. The VES covered a wide spectrum of activities aimed at protection of natural resources and improving the standards of living of communities through establishment of central village nurseries, woodlot and village shelterbelts by the local people. Considering the fact that women in rural communities are among the most disadvantage groups, the VES project included a women's forestry programme (WFP) that became one of the most significant components (Bristow, 1998).

The study before hand is an attempt to investigate the experience of the WFP as a pioneer effort in such a field through raising the following research question:

\section{To what extent the WFP in Shendi Area (Sudan) enhanced rural development endeavor?}

The main objective of the study was look for lessons to be learnt from the WFP initiative that would assist scientists and decision makers in the development sphere in improving their future development efforts.

\section{Research Focus and Methodology}

The study was carried out in Shendi area in the River Nile state (Sudan). Shendi town is located about $150 \mathrm{Km}$ north of Khartoum on the eastern side of the River Nile, 17-18 N, 23-24 E. The climate is hot desert. The Northern and Eastern -North wind are blowing to the area carrying sand. The annual rate of rain is $100 \mathrm{~mm}$. The area is suffering from severe desertification and moving sand dunes. The main economic activity is agriculture as it represents the main occupation of $80 \%$ of the population (Shendi Locality documents, 2007). 
In addition to reviewing the relevant secondary data, the field work for data collection was held during JulyAugust 2013. The data was collected from 100 women (main target group) in 12 villages from Shendi and Elmatamma provinces using the structured interviewing technique. As well, semi-structured interviews were carried out with village extension agents (VEAs), village leaders, and school teachers. Additionally, focus group discussions were conducted with women in every village, with men in 4 villages, with officials in Shendi and Elmatamma offices.

\section{Getting women involved forestry programmes}

\section{Results and discussions}

Historically, women in the River Nile State in Northern Sudan were not involved in agriculture or in managing large scale livestock. It only happened in a few cases when poor women could help in harvesting seasons. In addition to that, women were also restricted from working together with men. Village leaders were not convinced about the idea of involving women in the project. Mistakenly they assumed that women would refuse to participate in forestry activities. One of the village leaders in Elsseyal Elkabir said: "Why do you want to involve women in the project? Our women know nothing about tree growing; they just know how to burn them". However, Bristow (1992) argued that women will become involved in forestry programmes if they have a good reason to do so and if social and cultural conditions permit. Thus women were asked in a separate meeting, and they agreed immediately to participate in the project activities since most of the work will be inside their houses. In fact women have a potential to carry out the forestry activities as they had witnessed the change that occurred in the area. "Over the years we have seen the trees steadily disappearing. Now the wind blows sand everywhere. Many houses and compound walls have been covered by huge two-three meters high moving sand dunes" Safia, the headmaster of girl's primary school in Elsseyal Elkabir village said. As the project continued its activities, women felt more confident to participate with the communities outside. Then village men had no objection to women participation outside houses once they have completed their home domestic activities.

The WFP targeted rural women and school pupils as main stakeholders. The idea was to raise communities' consciousness about desertification and mobilize them to improve the environmental conditions. The project was implemented in two phases in the period 1994-2000 in 60 villages (Abbas, 2001).

\section{Training Village Extension Agents (VEA)}

The project opted for the Training of Trainers approach (TOT) as a mean to effective women participation. The idea was to train two ladies from each village to act as Village Extension Agents (VEA) that was to keep the knowledge and skills within the village to grantee sustainability. Besides, most of the villages are located far away from the WEP offices, which make the follow-up on a weekly basis by the WFP staff rather difficult.

The selection of the VEAs from each village was done by the women's union and the community committee in the village. In turn that was based on some criteria such as an active personality and being literate. Poorer families were preferred so that they would benefit from the monthly allowance that used to be paid to the VEAs. All the selected VEAs attend an intensive training course with WFP in Shendi town for one month. They were accommodated in the project's rest house.

The training courses tackled issues such as: environmental degradation with particular reference to desertification, establishment of home nurseries, growing vegetable, in addition to some basic aspects of records keeping, evaluation, meetings management and report writing. The WFP also provided the VEAs with the raw materials that they would need such as polythene bags, seeds, scissors and punchers. However, during the training courses they were well-informed how to be independent from the project in the future by using locally available material e.g. alternatives to polythene bags (WFP project documents, 2001).

In fact the VEAs were unanimously satisfied with the training they had received. As they applied their knowledge they started to have more questions and felt a desire for more training on specific aspects such as the production of fruit tree seedlings (Schorscher et al, 2001). Prior to the project termination in 2001, The WFP held two refreshment courses (three days each) for VEAs. All the VEAs who attended the courses felt it was good opportunity for them to exchange experiences, their success stories and benefit from each other's mistakes. As well, two Women's Forestry Societies were created in Shendi and Eddammer to take over and continue the WFP activities with technical support from the Forests National Corporation (FNC) (Abbas, 2001).

\section{Changing communities' environmental awareness}

This was the first activity that implemented by the VEAs in every project village for communities in general, and for women and school pupils in particular to raise their awareness about desertification, environmental degradation and their role in participation to solve the problem to some extent by planting trees everywhere in the villages. 
Table 1: Women's perception of causes of desertification

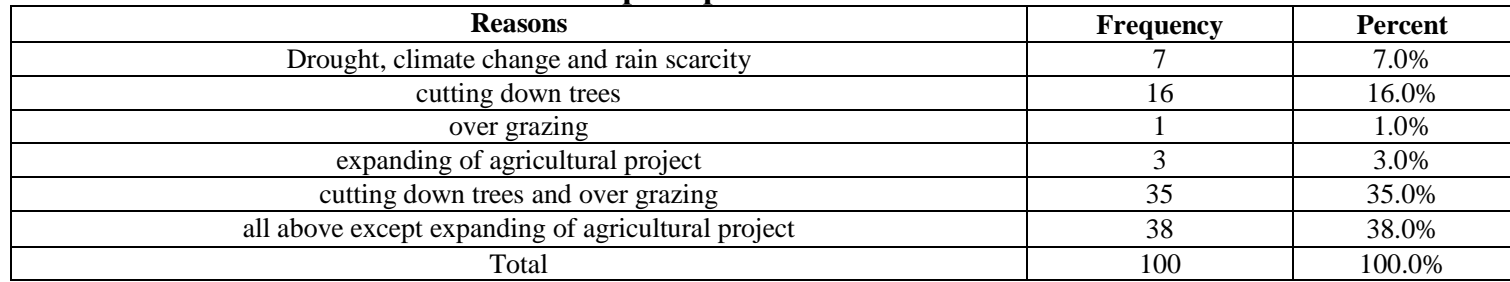

Source: Study survey 2013.

Table (1) displayed women's perception as concern the desertification process. $35 \%$ of respondents were of the opinion that cutting down trees and over grazing were the main reasons behind desertification. However, relatively small category ( $7 \%$ ) believes that desertification was linked to climate change. This indicates that rural women are aware of desertification and environmental degradation causes. Furthermore, table (2) demonstrated women's awareness about the relationship between trees and desertification process. According to the table, $93 \%$ of respondents acknowledged that tree planting has an impact on reducing desertification process in the area.

Table 2: Women's opinion concerning role of trees in desertification control

\begin{tabular}{|c|c|c|}
\hline Statement & Frequency & Percent \\
\hline trees help in desertification control & 93 & $93.0 \%$ \\
\hline no relation between trees and desertification & 6 & $6.0 \%$ \\
\hline I don't know & 1 & $1.0 \%$ \\
\hline Total & 100 & $100.0 \%$ \\
\hline
\end{tabular}

Source: Study survey 2013

During the field work of this study trees could be seen easily over houses' walls all over the villages, in addition to existence of big trees in some of schools. Women were very proud that they contributed to desertification control. The village leaders reflected that the strong wind that used to blow became less. Hence, they have planted windbreaks around their farms to reduce wind swiftness.

\section{Home Group Nurseries}

This was the main activity performed by all women. Women were involved in establishing home nurseries. They produced forestry tree seedlings in the first batches, and after get experienced they produced lemon, guava and ornamental tree seedlings. They raised seedlings to plant them inside and in front of their home yards. They were involved also in making the shade (mats) for the village nursery, as well as punching thousands of polythene bags for their home nurseries and for the village nurseries. Thus women participated in village nursery construction from inside their houses.

During group discussions, women's desire of seedling production and tree planting was evident. They considered that as one of their daily domestic activities. The village leaders and women themselves ascertain that when villages suffered from water shortages, women managed to keep their nurseries and trees alive by collecting water from the river and traditional wells.

Table 3: Types of seedlings produced and planted by women

\begin{tabular}{|c|c|c|}
\hline Item & Frequency & Percent \\
\hline forests trees & 7 & $7.0 \%$ \\
\hline fruit trees & 5 & $5.0 \%$ \\
\hline ornamental trees & 1 & $1.0 \%$ \\
\hline all the above & 79 & $79.0 \%$ \\
\hline forests and fruit trees & 8 & $8.0 \%$ \\
\hline Total & 100 & $100.0 \%$ \\
\hline
\end{tabular}

Source: Study survey 2013

Table (3) indicated that the majority of respondents (79\%) preferred to produce combination of forest, fruit and ornamental tree seedlings, compared to $8 \%$ who decided to raise forest and fruit tree seedlings. This exemplifies the extent of women's satisfaction with the training they received. In general village women seemed to feel that 
they had integrated all the basic skills acquired during training and many expressed their confidence in their newly acquired skills.

Women could sell the surplus seedlings and divide the profit between the group members. Although there was no good marketing in the same village as everyone produces seedlings, they could sell to relatives and friends in other villages that were not involved with the project. Nonetheless, table (4) reflected that only $39 \%$ of respondents were able to sell seedlings from their nurseries.

Table 4: Women's experience of selling seedling from their nurseries

\begin{tabular}{|c|c|c|}
\hline Statement & Frequency & Percent \\
\hline Yes & 39 & $39.0 \%$ \\
\hline No & 61 & $61.0 \%$ \\
\hline Total & 100 & $100.0 \%$ \\
\hline
\end{tabular}

Source: Study survey 2013

\section{Home Vegetable Gardens}

The objective of this activity was to grow vegetables by women in their homes for domestic use to enrich the family meals and improve the household nutrition status. Consequently families will save the money that could have been spent for purchasing vegetables from the market. According to Elasha (2006) the tradition of assigning small plots of lands near the homesteads as home gardens is deeply rooted throughout Africa. Women used to grow a whole range of plants that provide food and medicine to meet families' needs.

Table 5: Women's involvement in establishment of home gardens

\begin{tabular}{|c|c|c|}
\hline Statement & Frequency & Percent \\
\hline Yes, involved & 85 & $85.0 \%$ \\
\hline Not involved & 15 & $15.0 \%$ \\
\hline Total & 100 & $100.0 \%$ \\
\hline
\end{tabular}

Source: Study survey 2013

The table (5) showed that $85 \%$ of respondents were involved in establishing home gardens to grow vegetables. The group discussions revealed that women either used to grow vegetables individually i.e. everyone in her house, or as groups in houses whose owners left to the towns. Moreover in some villages women grew vegetables in agricultural land availed by their fathers or brothers.

Table 6: Women's perception concerning benefits of vegetables gardens

\begin{tabular}{|c|c|c|c|}
\hline Statement & Frequency & Percent & Valid Percent \\
\hline diversify family meals & 20 & $20.0 \%$ & $23.5 \%$ \\
\hline increase income by avoid buying vegetables & 4 & $4.0 \%$ & $4.7 \%$ \\
\hline all the above & 60 & $60.0 \%$ & $70.6 \%$ \\
\hline increase income by selling surplus & 1 & $1.0 \%$ & $1.2 \%$ \\
\hline Total & 85 & $85.0 \%$ & $100.0 \%$ \\
\hline Missing System & 15 & $15.0 \%$ & \\
\hline Total & 100 & $100.0 \%$ & \\
\hline
\end{tabular}

Source: Study survey 2013

The table (6) illustrated that most of the produced vegetable was for household consumption. Only $1.2 \%$ of those who grew vegetables agreed that gained money by selling surplus from their vegetables gardens. All others clarified that their benefit was in the form of diversifying family meals and/or saving money which could had otherwise being used for buying vegetables from market. During group discussions village women explained that once there is an occasion in the village (someone dies) they don't buy vegetable from the market, instead they collect it from home gardens.

\section{Spaghetti production programme}

Upon the request of several women this component of spaghetti production was added to the project. The poorer families, who were mostly headed by widows, organized themselves into groups. Each group consisting of 3-5 women was provided with a spaghetti machine, a sack of flour and polythene bags for packing the products (WFP documents, 2001). 
Table 7: Women's participation in spaghetti production programme

\begin{tabular}{|c|c|c|}
\hline Statement & Frequency & Percent \\
\hline Yes & 30 & $30.0 \%$ \\
\hline No & 70 & $70.0 \%$ \\
\hline Total & 100 & $100.0 \%$ \\
\hline
\end{tabular}

Source: Study survey 2013

According to table (7), only $30 \%$ of respondents participated in this activity. As the respondents explained this activity was designed for widows with children. During the field work of this study (2013) women explained that all women who obtained machines used to sell spaghetti. It was the only source of income for some poor families; they stated that this was the most important impact the project had on their lives. However, table (8) proved that only $16.7 \%$ of them were still producing spaghetti. During group discussions women explained that most of them stopped producing spaghetti as they failed to compete in local markets. The widows started to sell their productions for merchants in Shendi town, but again unfortunately the demand for their products became less as the quality was less comparing with what exists in the market.

Table 8: Women continuing spaghetti production

\begin{tabular}{|c|c|c|c|}
\hline Statement & Frequency & Percent & Valid Percent \\
\hline Yes & 5 & $5.0 \%$ & $16.7 \%$ \\
\hline No & 25 & $25.0 \%$ & $83.3 \%$ \\
\hline Total & 30 & $30.0 \%$ & $100.0 \%$ \\
\hline Missing System & 70 & $70.0 \%$ & \\
\hline Total & 100 & $100.0 \%$ & \\
\hline
\end{tabular}

Source: Study survey 2013

\section{Schools' programme}

The aim of this programme was to raise the environmental awareness of pupils (both girls and boys) and train them to establish school nurseries; plant, irrigate and protect trees in their schools and houses.

The project staff and VEAs with the assistance of teachers held lectures, and puppet shows in 26 schools. The pupils were trained to establish nurseries practically and to plant trees in their school compound. Trees friends' societies were formed in some schools. However this programme faced several constraints, namely: water shortage, nonexistence of fence, remoteness of school from villages and the long school vacation (3-4 months). In spite of these constraints, WFP staff encouraged schools to solve parts of their problems in collaboration with the local communities. The project provided water pipes for eight schools.

\section{The socioeconomic and environmental impact of WFP}

The table (9) illustrate that $74 \%$ of the respondents explained that the environmental impact of the project could be seen in the big numbers of trees that planted inside houses, in the streets, mosques, schools and other institutes in their villages, in addition they admitted that wind and dust storms became less. During group discussions women explained that on one hand they have produced plenty of forest tree seedlings upon farmers' requests so as to plant them as windbreaks around their farms. On the other hand, farmers added that they asked for VEAs support to show them how to establish their own nurseries in their farms. This indicated that the village men were appreciating and trusting the VEAs knowledge.

According to AbdelMagid (2008) the WFP has achieved so many positive results such as: harvesting the forest products (building pools, timber, firewood, vegetables and fodder), besides the establishment of shelterbelts contributed to stabilizing sand dunes to some extent. The latter, has encouraged villagers to stop shifting their houses to other areas. In addition, some of those who already shifted their houses came back and settled at their original places.

Table 9: Women's viewpoints concerning the project's environmental impact

\begin{tabular}{|c|c|c|}
\hline Statement & Frequency & Percent \\
\hline houses are full of trees & 4 & $4.0 \%$ \\
\hline trees were planted in schools, streets and mosques & 5 & $5.0 \%$ \\
\hline wind and dust became less & 2 & $2.0 \%$ \\
\hline all the above & 74 & $74.0 \%$ \\
\hline all above except wind and dust became less & 6 & $6.0 \%$ \\
\hline all above except trees were planted in schools & 9 & $9.0 \%$ \\
\hline Total & 100 & $100.0 \%$ \\
\hline
\end{tabular}

Source: Study survey 2013 
The great majority of the respondents expressed their satisfaction with the degree of social impact created by the WFP. According to $81 \%$ of respondents the project has positively influenced their social life as they used to meet with the group members; they paid visits to the other groups in the village, they created charity sandook to share during family crises, they started cooperatives, and they started to think of projects that are needed by the community in the area (table 10). Additionally, group discussions with VEAs revealed that they were of the opinion that the project has contributed notably to rural development in the area. Furthermore, key informants interviews in eight villages pointed out to the fact that village women encouraged men to give them a chance to be responsible for water sources management including collection the specified monthly fees from each household. Also they convinced village leaders to accept the idea of sending a lady from each village to receive training in Eddammer to work as midwife in her village. Schorscher et al 2001 reported that the relationship between men and women became stronger as men recognized women's skills. Women also started to follow literacy classes organized by VEAs and other educated women in their villages.

In the field of income generation, some women commenced handicrafts production and participated with their products in exhibitions held in Shendi and Eddammer towns. It is evident that women are now more confident and proud of themselves than before.

Table 10: Women's views concerning the project's impact on their social life

\begin{tabular}{|c|c|c|}
\hline Statement & Frequency & Percent \\
\hline meet always with the group member & 5 & $5.0 \%$ \\
\hline $\begin{array}{c}\text { exchange visits with other group, forms charity sandook, forms } \\
\text { cooperatives }\end{array}$ & 19 & $19.0 \%$ \\
\hline think of other projects needed in the area & 13 & $13.0 \%$ \\
\hline all the above & 44 & $44.0 \%$ \\
\hline All above except forming charity sandook and cooperatives & 19 & $19.0 \%$ \\
\hline Total & 100 & $100.0 \%$ \\
\hline
\end{tabular}

Source: Study survey 2013

\section{Conclusions}

The study demonstrated that women in rural areas have the potential to work in forestry and other rural development activities since their traditions were respected. Participation in the WFP enhanced women's sense of power. The character of the change brought about was mainly of psychological nature. However, social and to a lesser extent economic impacts were accredited.

Although the income generating initiatives were very much appreciated by the women and helped to consolidate their increased confidence, the economic impact was rather meager. Finally, the study established that the main element of success of the project lied in the intensive training of the well selected village extension agents (VEAs) who then returned to their villages and trained other women.

\section{References}

[1]. Abbas, S.E (2001). Training Rural Women for Environmental Improvement and Sustainable Livelihood in Northern Sudan. M.Sc. Thesis. Reading University, UK.

[2]. AbdelMagid, T. D. (2008). Overview of Community Forestry in the Sudan. Paper prepared as a contribution to IUCN Workshop, Khartoum-Sudan.

[3]. Asian Development Bank (2013). Gender equality and food security: women's empowerment as a tool against hunger. Mandaluyong City, Philippines.

[4]. Bristow S. (1992). A Research and Training Programme in Women's Forestry Project. Khartoum-Sudan.

[5]. Bristow S. (1998). Women's Extension Forestry Manual: A methodology from Northern Sudan. Printed in Great Britain by Antony Rowe LTD, Chippenham, and Wiltshire.

[6]. Burkey S. (1993). People First: a guide to self-reliant participatory rural development. ZED Books, London.

[7]. Dresner S. (2002). The principles of sustainability. Earthscan. London. Sterling, VA.

[8]. Elasha B.M. (2006). Role of Indigenous Knowledge in Climate Change Adaptation in Africa. Sudanese Social Forestry and Environment Newsletter-Volume II No.VIII.

[9]. Elbasher O. K. (2012). Training Impacts on Capacity building of rural leaders to participate in their community development in Kassala state-Sudan. Ph.D. thesis. Sudan University of Science \& Technology.

[10]. Elhadi M. A. (2006). Social and Environmental Evaluation of the FINNIDA project in Khartoum area of the Sudan. Ph.D. thesis, U of K Sudan.

[11]. Elobeid S. (2009). Gender Role in Adoption of Agricultural Innovation Of Sorghum in Kordfan State- Sudan. Ph.D. Thesis.

[12]. FAO (1996). Training for Agriculture and Rural development - Economic and Social development series No.54 .Rome.

[13]. FAO (2005). Building on Gender, Agrobiodiversity and Local Knowledge. Training Manual Produced by: Economic and Social Development Department. Food and Agriculture Organization of the United Nations Rome, Italy.

[14]. Humble M. (1998). “Assessing PRA for implementing Gender and Development” In Guijt, Irene and Meera Kaul Shah (eds.), The Myth of Community: Gender Issues in Participatory Development, London: Intermediate Technology Publications.

[15]. Korten D.C. (1990). Getting to the $21^{\text {st }}$ Century: Voluntary Action and the Global Agenda. Kumarian Press, West Hartford Connecticut, USA.

[16]. Sam T. and G. Shepherd (2011). Community forest management. A background Paper for: The United Nations Forum on Forests Secretariat UNFF9: "Forests for People, Livelihoods and Poverty Eradication" held at the United Nations headquarters in New York City, from 24 January to 4 February 2011. 
[17]. Schorscher J. AbdelSlam A. and Adam,A. (2001). Women's Forestry Project-Final Evaluation. Shendi-Sudan.

[18]. Shendi Locality documents (2007). Sudan.

[19]. Shephered A. (1998). Sustainable Rural Development. Macmillan Press LTD, Hampshire RG21 6XS and London.

[20]. Williams P.J. (1992). NGOs, women and forestry activities in Africa. Unasylva. An international journal of forestry and forest industries - Vol. 43 - 1992/4. FAO.

[21]. Women's Forestry Project documents (2001). Shendi and Khartoum-Sudan. 